\title{
Diversity and homogeneity among the early farming communities of Western Anatolia
}

\author{
Eylem Özdoğan \\ Istanbul University, Istanbul, TR \\ eyozdogan@yahoo.com
}

\begin{abstract}
Our knowledge of the Neolithisation of Western Anatolia has increased considerably in recent years. Being located beyond, but on the border of the formative zone of Neolithisation, the region has acted as a buffer in the dispersal of the Neolithic way of life farther to the west. Recent research in Western Anatolia has shown that Neolithic sites appeared in the second quarter of the $7_{\text {th }}$ millennium BC and had become widespread by the second half of the same millennium. There is now adequate data available on both the distribution of sites and the material culture in some subregions. In this context, this article will focus not on the Neolithisation process, but on the characteristic features of the sub-regions and the interaction between them.
\end{abstract}

IZVLEČEK - Naše vedenje o neolitizaciji zahodne Anatolije se je v zadnjih letih znatno povečalo. Glede na svoj položaj onstran, a useeno na meji formativne cone neolitizacije, je ta regija delovala kot ločitveno območje pri širjenju neolitskega načina življenja proti zahodu. Nedavne raziskave na zahodnem delu Anatolije so pokazale, da so se tam neolitska naselja pojavila v drugi četrtini 7 . tisočletja pr. n. št., razširila pa so se v drugi polovici istega tisočletja. Trenutno imamo že dovolj dostopnih podatkov o širitvi najdišč in materialne kulture v nekaterih podregijah. V članku se tako ne osredotočamo na proces neolitizacije, temveč na značilnosti v teh podregijah in na njihovi medsebojni interakciji.

KEY WORDS - Neolithic; Western Anatolia; Secondary Neolithisation

\section{Introduction}

The origin of Neolithic societies in Europe, which solidified connections between the Near East and the Aegean, has been discussed for over a hundred years. However, through time, not only what is implied by the term Neolithic but also the conceptual framework for approaching the problem has been considerably modified; as more data became available, not only our vision of the Neolithic, but more significantly, the questions being asked had to be reformulated.

The emergence and dispersal of the Neolithic way of life from the core area of its origin to the borders of Central Europe and the western coastal areas of the Mediterranean has been seen as a long multifarious process covering the period between the $10^{\text {th }}$ and $6^{\text {th }}$ millennium $\mathrm{BC}$; evidently, depending on the questions being asked or the modalities of our approach, there would be different ways to look into this vast territory, particularly in defining spatial boundaries. This paper will be concerned mainly with two distinct entities; the first area encompasses the geographical region where the Neolithic way of life first appeared and developed its main features. Different terms have been used to describe this region, such as 'the origin of civilisation', 'the Fertile Crescent', 'the primary zone of Neolithisation', 'the core area' or 'the formative zone' etc. (see Bailey, Whittle 2005; Özdoğan 2008; 2011; Asouti 2006; Zeder 2011). There are remarkable differences between these terms, not only in their meaning, but in the geographic and chronological boundaries of the region. In this paper, the main area where the basic features of the Neolithic way of life were form- 
ed will be referred to as the 'Formative Neolithisation Zone'. This is the main area where the first Neolithic communities appeared by the $10^{\text {th }}$ millennium BC and where cultural and technological developments occurred gradually in a dynamic process. This wide geographical area includes sub-regions such as the Levant, northern Mesopotamia/the Tigris and Euphrates Basin, the Zagros Mountains (?), Central Anatolia and Cyprus; even further distinctions can be made on the local level.

The second area is where the components constituting the Neolithic way of life appeared without precedent, although these same elements, sometimes contemporarily but generally earlier, emerge in the formative zone. The beginning of Neolithisation in these secondary areas, including western Anatolia, the Aegean, Greece, the Balkans, the Adriatic, Central Europe, the western Mediterranean, North Africa, and even the Caucasus, extends from the beginning of the $7^{\text {th }}$ to the end of the $6^{\text {th }}$ millennium BC. Here it is worth noting that the areas of secondary Neolithisation cannot be considered as a uniform entity; on the contrary, it comprises several distinct entities, each having its particular modalities. Direct or indirect connections to the formative zone, and the continuity of that relationship, the distribution of Neolithic components, the contribution of local elements to the Neolithic way of life, and/or the adaptation of Neolithic elements to a new natural/cultral environment all played a role in this process; due to the cultural and environmental variables and differences in Neolithisation processes, designating this area as a whole with a categorical name is rather difficult. In this respect, based on the presence of advanced Neolithic elements that evidently derived from the formative zone after being fully developed there, it seems proper to address them as the ' $S e$ condary Neolithisation Zone'. Even if grouping all of the regions noted above under this term is questionable, it seems proper to use it at least for western Anatolia, Greece, and the Balkans, regions that not only constitute the borderlands of the formative zone, but had sustained interaction with it.

The Neolithisation process in these secondary areas has been discussed since the first half of the $20^{\text {th }}$ century (Childe 1929; 1939; Milojčić 1949; Garašanin 1954; Renfrew 1987; Price 2000; Lichter, Meric 2005; Gatsov, Schwarzberg 2006; Krauß 2011). Many of the debates surrounding their emergence have arisen out of the conflict between diffusional and anti-diffusional approaches; nevertheless, trends have been changing since the 1990s, developing a multi-dimensional holistic approach to looking at the problem (see Harris 2003), and considering both cultural and demic movements in the westward expansion of the Neolithic way of life (van Andel, Runnels 1995; Zilhão 1997; Zvelebil, Lillie 2000; Zvelebil 2001; Bogucki 2003; Perlès 2003; Özdoğan 2011; Budja 2009; 2013). As will be elaborated below, recent work in western Anatolia not only reveals apparent similarities between the formative and secondary zones, but also presents direct evidence of interregional connections.

Research in western Anatolia in the last two decades has demonstrated that the Neolithic way of life emerged almost simultaneously in Western Anatolia and Greece, expanding to the Balkans just a short time later. Although this was a rapid process in secondary areas, Neolithic settlements in the initial phase of dispersion seem to have been sparse. In the second half of 7 th millennium BC, this dispersal gained momentum, but the massive expansion of the Neolithic way of life took place at the end of the same millennium or the beginning of the next. Thus the apparent leap of dispersal from Central to Western Anatolia is part of a more complex picture, which must be examined in accordance with the dynamics behind Neolithic dispersal from the formative zone (Brami 2015).

In the course of recent decades, with the onset of new excavations, our knowledge of the material assemblages of Western Anatolia has increased considerably; it now is possible to detect several components that indicate a close relationship with the formative zone. It seems that demic diffusion played an imported role in the Neolithisation of Western Anatolia, Greece, and the Balkans. In this respect, significant contributions have been made by archaeogenetic studies, gradually providing ample new data to answer questions relating to the Neolithisation process. At the present point of research, although there has been a number research projects, some still ongoing, based on genome studies to understand the interaction between the sub-regions of the Formative Zone and the area of Secondary Neolithisation, mainly due to the geographic and as well chronologically uneven distribution of samples, some considerable controversies still need more time to be resolved. On the other hand, evidence of the contribution of early Near Eastern farmers to the European gene pool is gradually increasing (Pinhasi et al. 2005; Thomas et al. 2013; Fort 2015; Mathieson et al. 2015; Lazaridis et al. 2016; Hofmanová et al. 2016). 
A recent DNA project which compares the genes of contemporary populations in Northwestern Anatolia with samples from the Neolithic layers of Barcin and Neolithic sites in Greece has revealed certain genetic connections between these two regions (Hofmanová et al. 2016). However, genetic studies, especially from Anatolian sites, are still extremely few. Barcin is the only Neolithic site in Western Anatolia to compare to the whole of Europe. As well as questions about the genetic composition of Western Anatolia, there are many more questions about the differences between the Neolithic societies of Western and Central Anatolia and the unknown Mesolithic populations. The genetic connection between Anatolia and the Near East has also not been ascertained thoroughly. Therefore, given the present state of genomic research, it is difficult to define clear routes for Neolithic expansion; moreover, the results of genetic analysis have to be correlated with the archaeological evidence. In this respect, there is a significant discrepancy between the archaeological evidence and the genome studies noted above; a recent assessment of the archaeological evidence of Northwest Anatolian Neolithic sites clearly reveals a difference between sites in eastern and western parts of Thrace, indicating that the Barcin-related as- semblages stopped in the area of Istanbul without expanding into Thrace (Özdoğan 2014a). Thus, the archaeological and genomic results have somehow to be considered together before making conclusive remarks. Contrary to the differences between the Neolithic assemblages on the eastern and western sides of the Sea of Marmara, similarities with mainland Greece are evident, which could be interpreted either as evidence of a direct connection between the two regions or an indication of their common origin.

Although there are similarities, cultural differences can be discerned between large cultural areas and at the local level. Thus, it is difficult to envisage an identical process of Neolithisation for the whole area or to confirm the same mechanism for the process. Detailed studies of micro-regions, as well as enabling the summarising of local developments, more significantly provide the means to develop supra-regional perspectives; otherwise, as exemplified above, what seems similar in an overview, either in a cultural or genetic analysis, may give way to new controversies.

Research in Western Anatolia has shown that there are cultural differences within the region itself. This paper aims to present the differences and similari-

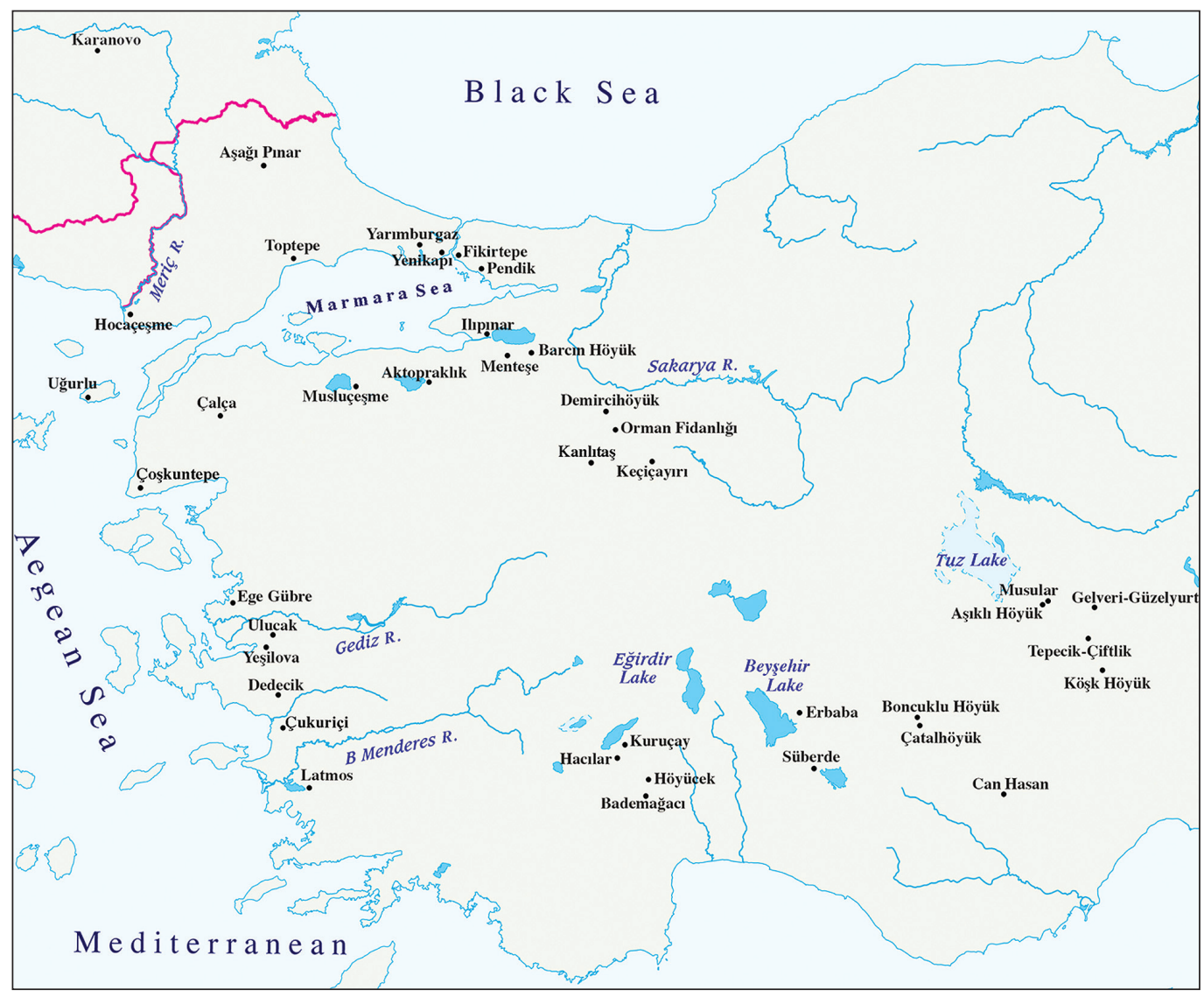

Fig. 1. Sites mentioned in the text. 
ties between the adaptations of Neolithic elements in various areas of this region, although some areas still remain undocumented.

\section{Studies of the Neolithic in Western Anatolia}

Western Anatolia has three areas with distinct Neolithic features: the Lakes District/Southwest Anatolia, Central-west Anatolia and Northwest Anatolia (Fig. 1). The Lakes District was a priority for archaeological investigations from the very beginning of Neolithic research in Anatolia. The first studies began in the 1950s with James Mellaart's work at Hac1lar, and continued in the years immediately after from 1957 to 1960 (Mellaart 1970). Hacilar and Çatalhöyük in Central Anatolia were again excavated by Mellaart between 1961 and 1965, both revealing the first evidence of Neolithic communities on the Anatolian plateau, the existence of which had been ruled out (Mellaart 1967). The Hacilar excavations in the 1950s were a turning point not only for knowledge of the region's western areas, but also in the history of archaeological research in Anatolia. With the excavations at Hacilar, the Near Eastern chronological denominations were transferred to Anatolia, mainly deriving from Tarsus Gözlükule; the stage at which painted vessels intensified at Hacilar was seen to be contemporary with Halaf culture, so it was termed the Early Chalcolithic. Later, with the excavations at Çatalhöyük, this chronology was also adapted to the interior regions of Anatolia (Schoop 2011.151-152). Thus, these first studies were instrumental in defining the chronology and terminology still used for Anatolian prehistory.

After Hacılar and Çatalhöyük, excavations at Erbaba (1964-1965) and Suberde (1969-1978) on the outskirts of the Beyssehir and Suğla lakes were conducted by Jacques Bordaz (Bordaz 1973). For a long time, however, the definition of the Neolithic cultures of Anatolia was based mainly on the evidence from Hacilar and Çatalhöyük, and usually disregarded results from other sites. In this respect, with the excitement triggered by the finds at Catalhöyük and Hacilar, the quest to look for the origins of the European Neolithic in the Near East until 1980s were mainly confined to comparisons based on the material evidence from these two sites. Research in the Lakes District resumed in the 1980s, beginning with some soundings on the periphery of the Hacilar mound between 1985 and 1986 by Refik Duru (1989), who also excavated Kuruçay from 1978 to 1988 (Duru 1994) and Höyücek from 1989 to 1992 (Duru, Umurtak 2005). Between 1993 and 2010,
Duru also worked at Bademağacı with Gülsün Umurtak (Duru 2008). In addition to these excavations, surveys were conducted by Mehmet Özsait (1993), illustrating the intensity of settlement during the Neolithic and Early Chalcolithic.

Neolithic research in the northwest began at the same time as the research in the Lakes District. Located on the eastern side of the Bosphorus, Fikirtepe was excavated by Kurt Bittel and Halet Çambel between 1952 and 1954 (Bittel 1969). Researching a site contemporary with Fikirtepe, Sevket Aziz Kansu took some soundings at Pendik in 1961 (Kansu 1963). Edibe Uzunoğlu began a salvage excavation at Pendik in 1981 (Harmankaya 1983), which was continued by Alpay Pasinli in 1992 (Pasinli et al. 1994) and Zeynep Kizlltan between 2012 and 2013 (Kiziltan 2013). The assemblage revealed there was similar to Fikirtepe in terms of pottery, architecture, and burial customs (Özdoğan 1983). Due to the conventional assumption that Neolithic settlements did not exist in this region, the dating of these sites long remained controversial. In 1979, Mehmet Özdoğan dated materials from the Fikirtepe excavations in his PhD thesis (Özdoğan 1979) and concluded that the Neolithic societies in and around the Bosporus were part of a single cultural group, the 'Fikirtepe Culture', due to the distinctive features observed at Pendik and Fikirtepe (Özdoğan 1983). After the beginning of excavations at Ilipinar at the end of the 1980s, the Fikirtepe material could finally be radiocarbon dated. Despite differences in architecture and subsistence pattern, the pottery of layers X-IX at Ilpinar is similar to assemblages of other sites labelled as 'Fikirtepe Culture', so the date of the sites could be securely established to the beginning of $6^{\text {th }}$ millennium BC (Özdoğan 1999).

The architectural remains and material culture at Fikirtepe and Pendik are quite different from those at contemporary settlements in the Lakes District and Central Anatolia. The architecture of these sites consists of simple huts, and the faunal evidence points to intensive fishing and mollusc gathering; likewise, finds such as grindstones and flat axes, which are usually the markers of agricultural communities, are few in number (Özdoğan 1979). In addition to these features, the presence of microliths and relatively small bullet cores led Özdoğan to define the costal settlements like Fikirtepe and Pendik as descendants of local Mesolithic communities known from surface surveys (Özdoğan 1999). The architecture, subsistence patterns, and chipped stone technology reminiscent of Mesolithic traditions suggest 
continuity between Mesolithic communities and Fikirtepe-related sites. The pottery assemblages also support this assertion, given the predominance of simple cooking pots for domestic use and mostly dark and matt surfaced wares, which are unlike the red-slipped ware known from Neolithic sites in western Anatolia.

Following the excavations of Ilipinar from 1987 to 2002 , the same team under the direction of Jacob J. Roodenberg, continued their work at Menteşe from 2000-2005 (Roodenberg, Alpaslan-Roodenberg 2013; Roodenberg et al. 2003). With the excavation of Aktopraklık (Karul, Avcr 2013) and Barcin in 2004 (Gerritsen et al. 2013a), knowledge of the Neolithic communities of the southern and eastern parts of the Sea of Marmara considerably increased. The basal layers of Barcin, Aktopraklık, and Menteşe are dated to the second half of the 7 th millennium BC, revealing pottery assemblages similar to, or slightly different from, that of the 'archaic phase' of Fikirtepe; it thus seems evident that the initial stages of 'Fikirtepe Culture' began in those regions at a much earlier date.

There are significant differences among the excavated sites in Northwest Anatolia, demonstrating the effect of local environments and traditions. Coastal settlements like Fikirtepe and Pendik and mountain threshold sites like Aktopraklık show features reminiscent of their local Mesolithic communities, whereas Ilıpınar, Menteşe and Barcın predominantly feature elements typical of agricultural villages (Karul 2011). Yenikap1, excavated between 2008 to 2013 on the western side of the Bosphorus, and Yarimburgaz Cave at the northern end of Küçükçekmece Lagoon also have significant localised differences (Kiziltan, Polat 2013; Özdoğan 2013).

Due to apparent changes in the topography of the coastal areas of Western Anatolia and the heavy alluvial fill that has accumulated in the valleys and plains, the Aegean littoral is an area where localising Neolithic and Early Chalcolithic settlements is rather difficult. Therefore, the area has long remained in obscurity. An initial reconnaissance of the area, although not intensive, was conducted by David French (1965) in the 1960s and by Recep Meriç (1993) in the 1980s. Despite some small-scale research following these studies, until recently it was still an area where no Neolithic excavations had taken place. Knowledge of the Neolithic in this region began to emerge with the excavation of Ulucak beginning in 1995 (Çilingiroğlu et al. 2004; 2012).
Following this initial work on Neolithic communities in the eastern Aegean, excavations were conducted at Dedecik in 2003, Ege Gübre and Yeşilova in 2004, and Cukuriçi in 2007 (Lichter, Meric 2012; Sağlamtimur 2012; Derin 2012; Horejs 2012). All of these sites, being located by the alluvial valleys of the Gediz and Menderes rivers, were buried under thick alluvial deposits. In the southernmost area of these sites, rock shelters in the Bessparmak/Latmos mountains have revealed rock paintings dating back to the Late Neolithic-Early Chalcolithic (Peschlow-Bindokat, Gerber 2012). Although there are some difficulties regarding the dating of these paintings, they have some features reminiscent of similarly dated painted pottery and figurines from the Lakes District.

Far fewer studies have been made in the northeastern part of the Aegean. The site of Coşkuntepe discovered by Jurgen Seeher in 1990 on the southwestern edge of Biga peninsula, and Uğurlu located close to the coast on the western side of Gökçeada/Imroz, shows that this region has been inhabited since the Early Neolithic period (Seeher 1990; Erdoğu 2013). It is also possible to assess Hoca Çeşme as a northern Aegean site due to its location on the Maritza River (Özdoğan 2013). Having been inhabited since the second half of $7^{\text {th }}$ millennium $\mathrm{BC}$, the early phase of this settlement was closely connected with developments in the Aegean, but from the $6^{\text {th }}$ millennium onwards it shows closer similarities with the central parts of Thrace, mainly with those known as the Karanovo assemblages.

\section{Neolithic chronology and pottery assemblages}

The earliest dates on the appearance of Neolithic elements outside of its formative zone are not earlier than the second quarter of $7^{\text {th }}$ millennium $\mathrm{BC}$, according to newly calibrated dates (see Reingruber 2015 and Weninger et al. 2014) from sites including Ulucak, Çukuriçi, Knossos, and Franchthi Cave, located respectively on the western and eastern side of the Aegean. These data demonstrate that the first leap of the Neolithic to the 'west' did not take place along a frontier line, but occurred dynamically across a wide area (Fig. 2). In this respect, it is of interest to note that the excavators of these sites, based on certain analogies, have pointed to the different regions of the formative zone. In this regard, Ulucak, for example, located along the eastern end of the Gediz valley, which provides a natural route connecting the Aegean littoral with inner Anatolian plateau, has revealed red-coated floors and the subsequent pottery tradition (Ciilingiroğlu, Çakırlar 2013). 


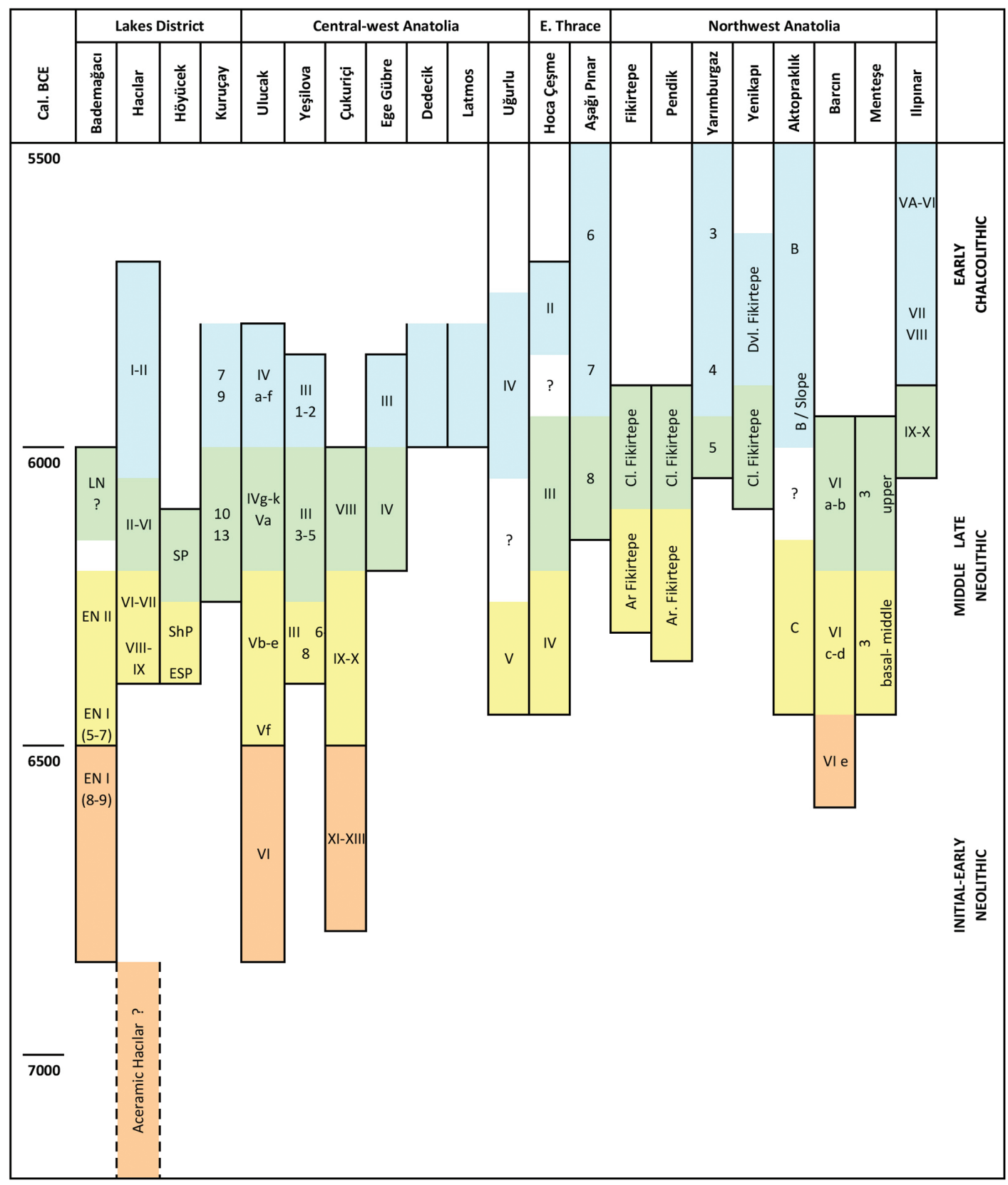

Fig. 2. Chronological table of sites in Western Anatolia.

On the other hand, the newly exposed early layers in Çukuriçi, located in the same area as Ulucak, have been associated with the Neolithic assemblages of the Levant and northern Mesopotamia, due to the presence of lithic tools and some other stone implements that bear the characteristic features of the PPN tradition (Horejs et al. 2015). It is also often noted that Knossos and Franchthi had connections with the Eastern Mediterranean and the Levant (Perlès 2001; Efstratiou 2013). Likewise, the Neolithic assemblage of Ege Gübre, which dates to a slightly later period, has been compared to the contemporary sites in the Eastern Mediterranean and Cyprus, mainly concerning the presence of impresso deco- ration and to features of the architectural remains at the site (Sağlamtimur 2012). The relationships between different areas of the formative zone show that the expansion of the Neolithic was more complex than previously assumed.

In recent years, in characterising the period in the newly Neolithised regions outside the formative zones, a number of different suggestions have been made (see Reingruber 2015). Pottery, seen as one of the most characteristic elements of the westward expansion of the Neolithic, and has been at the centre of these debates. However, the present data suggest that in the earliest stages of expansion, pottery 
was not among the 'unavoidable' components of the Neolithic way of life. Pottery emerged on the Anatolian Plateau at the end of the $8^{\text {th }}$ millennium $\mathrm{BC}$, and was rarely used until approx. 6700-6600 BC. It then existed mostly as coarse, plant-tempered, thick-walled and simple ware (Özdoğan 2009). Pottery from this period in Central Anatolia is defined as 'Early Tradition' by Serap Özdöl, and defined in detail by Suberde and Çatalhöyük (Özdöl 2012). Therefore, the existence of little pottery or none at the earliest Neolithic settlements in the Aegean or in Western Anatolia is consistent with the central and eastern parts of the peninsula. Layer VI in Ulucak, where no pottery has been encountered, is also consistent with this picture (Cilingiroğlu et al. 2012). Recently discovered layers at Çukuriçi present a similar situation; although no detailed published description of the pottery vessels is available yet, the excavators note that pottery is insignificant in the material assemblage of layers XI-XIII of the mound (Horejs et al. 2015.305). Aceramic Hacilar and Bademağacı ENI 9-8 present a coherent picture, although the dates of both sites and the presence of pottery in Aceramic Hacilar are quite controversial (see $\mathrm{Bra}$ mi, Heyd 2011; Özdoğan E. 2015).

While pottery from layer VIe at Barcin in Northwest Anatolia is slightly later than the earliest pottery in Central Anatolia, dating to $6600 \mathrm{BC}$, the presence of fewer coarse and simple wares is remarkable. At Barcin, the pottery assemblage includes simple planttempered thick-walled spherical vessels, baked at low temperatures (Gerritsen et al. 2013b.Fig. 11-14). Based on this, pottery production in Northwest Anatolia is therefore reminiscent of the 'Early Tradition' in Central Anatolia, although with later dates.

The scarcity of early Neolithic settlements, the diversity displayed in the quality and quantity of pottery types recovered is remarkable; thus we termed this stage as the 'initial phase' (Özdoğan E. 2015.51). As far as can be understood, there is evidence of village life at all the settlements, as well as full adaptation to agriculture, animal husbandry, and their associated technologies. Thus, the presence or absence of pottery relates to the process of adapting to the newly emerging technology of pottery production rather than to the expansion of the Neolithic. In terms of the first pottery with these coarse and simple features, no trace has yet been encountered in the Lakes District or Central-west Anatolia. It seems that pottery appeared in these areas when it was more developed or, alternatively, it represents a process independent from the Central Anatolian early pottery tradition.

From the mid-7th millennium $\mathrm{BC}$, consistent with the increase in the number of new settlements, pottery became a common commodity. Defined as the DFBW (dark-faced burnished wares) group or the 'Middle Tradition' by Özdöl (2012), the pottery from this period shows some differences from region to region. The early pottery in Central-west Anatolia includes simple thin-walled spherical vessels in brown, cream and red tones known from Ulucak Vf, which is reminiscent of the DFBW tradition. The published assemblage from Ulucak Vf-b, Yeşilova III8-6, and Cukuriçi X-IX indicates that S-profiled bowls and the use of a red slip increases over time (Cilingiroğlu et al. 2012; Derin 2012; Horejs 2012) Although rather rare, vertical lugs and small horizontal handles with flat- or disc-shaped bases are distinctly characteristic of these assemblages. The pottery assemblages of the Lakes District present a similar picture; cream, brown and red tones dominate the pottery of Bademağacı ENI-II, Höyücek ESP-ShP1, and Hacilar IX-VIII (Duru 2008; Duru, Umurtak 2005; Mellaart 1970). In this area, bowls and open forms with thin walls and flat bases have been found over a wider area. The number of vertical lugs and the use of red slip also increase over time.

Although there seem to be some stylistic difference between the Uğurlu and Hoca Çeşme assemblages, both dating to the latter half of the $7^{\text {th }}$ millennium $\mathrm{BC}$ in the northeast Aegean, it is possible to see highly burnished, thin-walled, high quality ware in vibrant tones of red and black, especially in Hoca Çeşme (Erdoğu 2013; Karul, Bertram 2005). The vessels are generally small and have sharply cut S-profiles. Contemporary with the aforementioned Hoca Cessme ware, in other parts of Northwestern Anatolia what has been termed 'Archaic Fikirtepe' ware predominates, mainly at sites including Barcin VId-c, Aktopraklık C, and in the basal layers of Menteșe, Fikirtepe, and Pendik; this material features small and simple closed shapes, mainly bowls and holemouth jars (Gerritsen et al. 2013a-b; Karul, Avcr 2011; Roodenberg et al. 2003; Özdoğan 2013). These are in cream, light tones of red, dark brown and different shades of grey. Vertical tubular or horizontal lugs, and flat bases are common; the quality of craftsmanship improves through time, with the walls of the vessels becoming thinner. Disproportio-

1 ESP is the Early Settlement Phase, ShP is the 'Shrine Phase' and SP is the 'Sanctuaries Phase'. 
nately large horizontal lugs are among the most characteristic features of 'Fikirtepe Culture', mainly at Pendik and at Fikirtepe (Fig. 3), although they are dated to a slightly later period than other sites in the southern part of the Sea of Marmara.

In the last quarter of the 7 th and the beginning of the $6^{\text {th }}$ millennium $\mathrm{BC}$, pottery groups show remarkable dif-

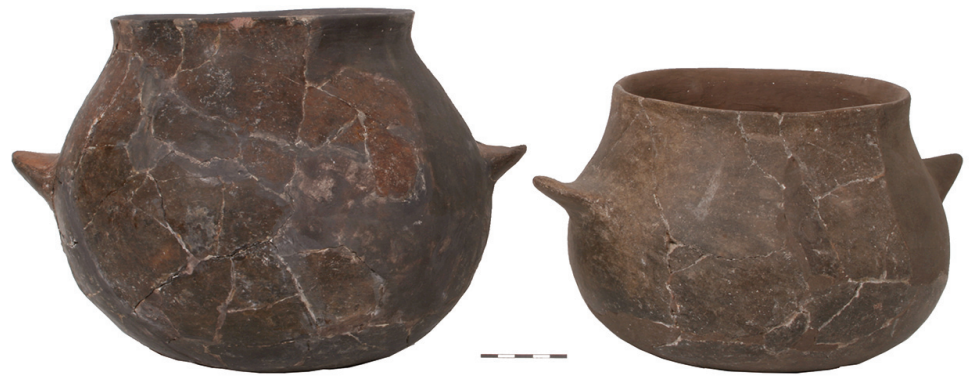

Fig. 3. Globular jars from Fikirtepe (after Özdoğan 2013.Fig. 7).

ferences and more variety in form. Certainly, the distinctive feature of this period is the style of decoration; the different noteworthy pottery traditions include vessels decorated with light on dark paint in the Lakes District (Duru 2008; Mellaart 1970), monochrome red slipped wares in Central-west Anatolia and vessels with a dark, matt surface without decoration or, rarely, with narrow incised decoration in Northwest Anatolia (Cilingiroğlu et al. 2012; Derin 2012; Sağlamtimur 2012; Horejs 2012; Özdoğan 2013).

The percentage of painted pottery revealed in $\mathrm{Ha}$ clar V (Fig. 4) increases after Layer VI in the Lakes District (Mellaart 1970). Together with the painted wares' sharper S profiles, the emergence of carinated bowls is observable. The painted pottery of Central Anatolia had been associated with Halaf painted pottery by Mellaart, mainly due to the presence in both regions of open bowls and necked jars with painted decoration. In Central-west and Northwest Anatolia, painted decoration (Fig. 5) is seen very rarely. However, red-slipped vessels are quite frequent and S-profiled vessels tend to increase over time. One of the changes in this area is the appearance of impresso decoration in the late $7^{\text {th }}$ millennium BC (Çilingiroğlu 2016). This type of decoration is frequently seen at all the settlements in the area, especially at Ege Gübre (Sağlamtimur 2012). While impresso decoration appears almost simultaneously in the Lakes District, where the percentage of impresso is relatively quite low, its appearance being almost as infrequent as the painted ware in Central-west Anatolia (Duru 2008). Impresso decoration emerges in the early $6^{\text {th }}$ millennium BC in Northwest Anatolia, at Aktopraklık B (Slope), Ilıpınar VIII, and Yarmburgaz 5 (Karul, Avcr
2013; Thissen 2001; Özdoğan 2013). In all three regions, the pottery tradition continues by retaining its former features during the $6^{\text {th }}$ millennium $\mathrm{BC}$, but a range of new forms are added, in particular necked jars and large storage vessels. There is an increase in the number of incision-decorated vessels, particularly among the 'Classical Fikirtepe' stage in Northwest Anatolia, and painted ware in the Lakes District. In general, with the exception of the ware with sophisticated decoration of the Lakes District, pottery of the $6^{\text {th }}$ millennium $\mathrm{BC}$ in most other regions is coarser compared with pottery in the earlier stage.

\section{Similarities and differences in the material as- semblage}

\section{Subsistence strategies}

Animal husbandry and agriculture had been fully adopted by the initial stages of the Neolithic in Western Anatolia. Recent studies have demonstrated that domestic sheep and goat were present in the central
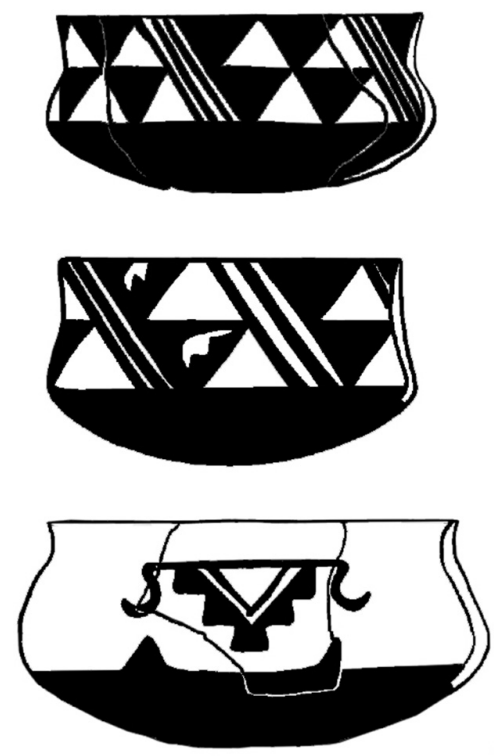

Fig. 4. Painted vessels from Hacular V (after Mellaart 1970.Tabs. 277, 279). 


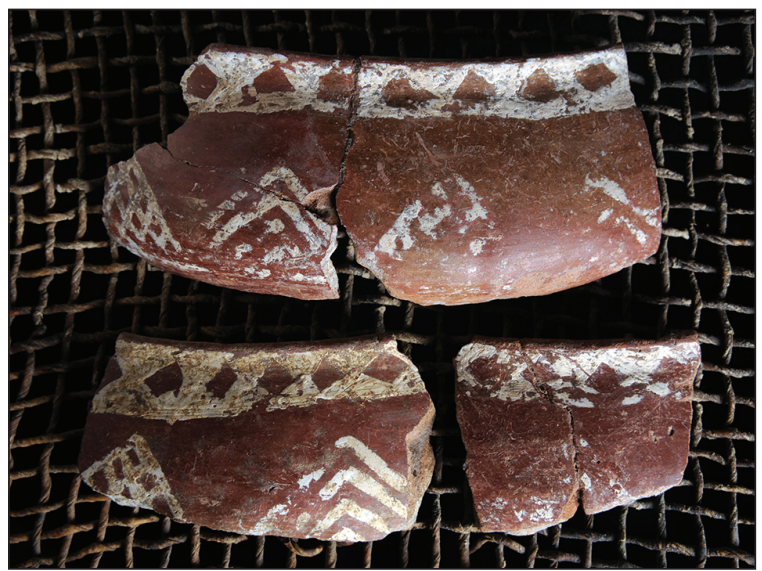

Fig. 5. Painted pottery from Aktopraklhk B, Aktopraklik project archive.

and western parts of the Anatolian Plateau from the early phases of the Neolithic, but cattle and especially pig were domesticated through different processes (Arbuckle 2013; Ottoni et al. 2013). Intensive wild cattle hunting seen from the Aceramic phase onward in Central Anatolia and the presence of bull symbolism in the area is known from Çatalhöyük; however, the appearance of domesticated cattle is dated to the middle of the $7^{\text {th }}$ millennium BC. This is a thousand years later than the domestication of sheep and goats, which took place in the $8^{\text {th }}$ millennium BC. Domestic cattle remained uncommon in the region, and auroch hunting continued until the $5^{\text {th }}$ millennium BC (Arbuckle 2013.1808). More striking data are available for pigs; Central Anatolian Neolithic societies hunted pig very infrequently, and the emergence of domestic pigs in the region dates to after the Neolithic. Domestic pigs existed in the northern part of the region in the middle of the $5^{\text {th }}$ millennium $\mathrm{BC}$, while in southern parts, evidence of domestic pig is only found in the Bronze Age (Arbuckle 2013.1809). In the periphery of Central Anatolia, however, domestic cattle are present from the early stages. Likewise, it is understood that domestic pigs are encountered at the first Neolithic settlements in the Lakes District and Central-west Anatolia and that local pigs were also domesticated. It has also been suggested that the existence of domesticated pig dates to the early $6^{\text {th }}$ millennium $\mathrm{BC}$ in Northwest Anatolia, and the method and impetus for the domestication of pig then passed through Central-west Anatolia (Ottoni et al. 2013; Arbuckle et al. 2014). The appearance of domesticated pig is not the only novelty in Northwest Anatolia in the early $6^{\text {th }}$ millennium BC. At the same time, impresso decoration and mud brick architecture has been encountered at Aktopraklık B (Slope) (Karul, Avcı 2013); shortly after Aktopraklık B, both impresso pottery and mud brick architecture seem to have dispersed to the regions north of Bursa, as evidenced at Ilip1nar (Roodenberg, Alpaslan-Roodenberg 2013). Although both the presence of domesticated pig and impresso decoration shows ties with Central-west Anatolia, the tradition of mud brick walls with buttresses indicates sustained interaction with the southern parts of Central Anatolia and the Lakes District. Another important feature of Northwest Anatolia in terms of subsistence patterns is the diversity of data on fishing and mollusc gathering. Although there is some evidence of the use of marine or lacustrine sources at sites within the Central-west Anatolia and Lakes District, the consumption of marine fauna is remarkably high in Northwest Anatolia, especially at coastal settlements. Here, mollusc gathering and open-sea fishing were important activities in the food economy, together with the hunting of game animals (Boessneck, von den Driesch 1979). Dairy products are also characteristic of the region; residue analyses from different sites in Northwest Anatolia show that the use of dairy products dates from the late $7^{\text {th }}$ millennium BC (Evershed et al. 2008; Thissen et al. 2010).

\section{Architecture and village patterns}

Different traditions regarding building materials and plan-types, as well as settlement patterns are to be seen in Western Anatolia during the Neolithic period. From the earliest stage, some structures with terrazzo-like and red-coated floors have been recovered, mainly at sites such as Ulucak VI, Bademağacı EN 8, and the so-called Aceramic Hacilar (Çilingiroğlu et al. 2012; Duru 2008; Mellaart 1970). Despite our limited knowledge of the settlement layout, the presence of wattle and daub structures has been attested at Ulucak, while structures with mud brick walls exist at Hacilar. In the Lakes District, mud brick architecture is a characteristic feature of the Neolithic and Early Chalcolithic periods and, as known from Kuruçay and Bademağacı, stone foundations are also to be seen in some layers. The use of wattle and daub architecture seems to have continued from the earliest layer up to the end of Layer V at Ulucak (Cilingiroglu et al. 2004; 2012). On the other hand, as revealed at Çukuriçi, buildings with stone foundations were also built in the region (Horejs 2012). However, later mud brick architecture with stone foundations replaced the use of wattle and daub, as indicated at Ulucak IV, Ege Gübre and Yeşilova (Çilingiroğlu et al. 2012; Sağlamtimur 2012; Derin 2012).

Different traditions were also in present at the same time in Northwest Anatolia. While there are simple 
wattle and daub huts in coastal settlements and Aktopraklik, which is located in a mountain threshold area, settlements like Barcın, Menteşe and the early layers of Ilıpınar (X-VIII) have a well-organised rectangular village pattern with wattle and daub or mudslab structures (Özdoğan 2013; Karul, Avcı 2013; Gerritsen et al. 2013a; Roodenberg et al. 2003). But the most important difference between these two groups lies not in the structural plans, but in the functions of these structures. In settlements with rectangular plans, the organisation of the interior of the structures shows that these buildings bore the characteristic features of 'Neolithic dwellings' in terms of installations, storage facilities, the distribution of finds and the multi-functional purpose of the house as shelter, storage space, and living space, whereas structures in coastal settlements remain relatively simple huts. The huts at coastal sites appear as simple shelters compared to the concept of the house that existed during the Neolithic in Anatolia. With the $6^{\text {th }}$ millennium BC, architecture and settlement plans were subject to strict rules in Northwest Anatolia (Karul, Avcı 2013). In Aktopraklık B and Ilıp1nar VI-VA, buttressed buildings with mud brick walls are organised adjacent to one another in a curvilinear or circular pattern. Built according to the same dimensions, structures are organised around a large central courtyard. This architectural pattern, specific to this region, developed with time, its earliest examples being the wattle and daub structures built adjacent to one another at Barcin in level VId (Gerritsen et al. 2013a.95). Here, open spaces in front of the houses are used as open courtyards where the activities of everyday life took place. A more or less similar pattern consisting of structures in lines around a large courtyard (Fig. 6) is also characteristic of the Lakes District. Structures in two clusters in Hacilar VI are referred to by Mellaart as part of a settlement pattern with a circular plan similar to the rectangular layout of Hacilar II and the round layout in Hacilar I (Mellaart 1970.10-11, 28-29, 77). Mud brick walls with buttresses also appeared in the early $6^{\text {th }}$ millennium in the Lakes District; the structures in Hacilar I and Kuruçay 7 (with stone foundations) are buttressed (Mellaart 1970.Fig. 35; Duru 1994. Fig. 24). Almost contemporaneously, mud brick architecture also appears in Ulucak, but here the layout of the settlement is different, as the buildings were separated from each other by narrow streets; still, closed courtyards are present, not as shared spaces, but as parts of specific structural units (Cilingiroğlu et al. 2012.Fig. 3). This settlement pattern is currently attested only in this region, and specifically in Ulucak IV. Layer III at Ege Gübre in the same region presents a different picture; here, structures were placed around a wide open space, seemingly an open courtyard (Sağlamtimur 2012.Fig. 2).

\section{Burial customs}

During the Neolithic, one of the differences between the sub-regions in western Anatolia is the burial customs. In the formative zone of the Neolithic, early in the period, intramural burial was the common practice. Along with simple inhumations in pits, there was a diversity of burial practices, such as skull removal and, occasionally, treatment of skulls, collective burials, and secondary burials, or post-burial practices etc., but all taking place within the settlement (Erdal 2015). One of the most significant chan-

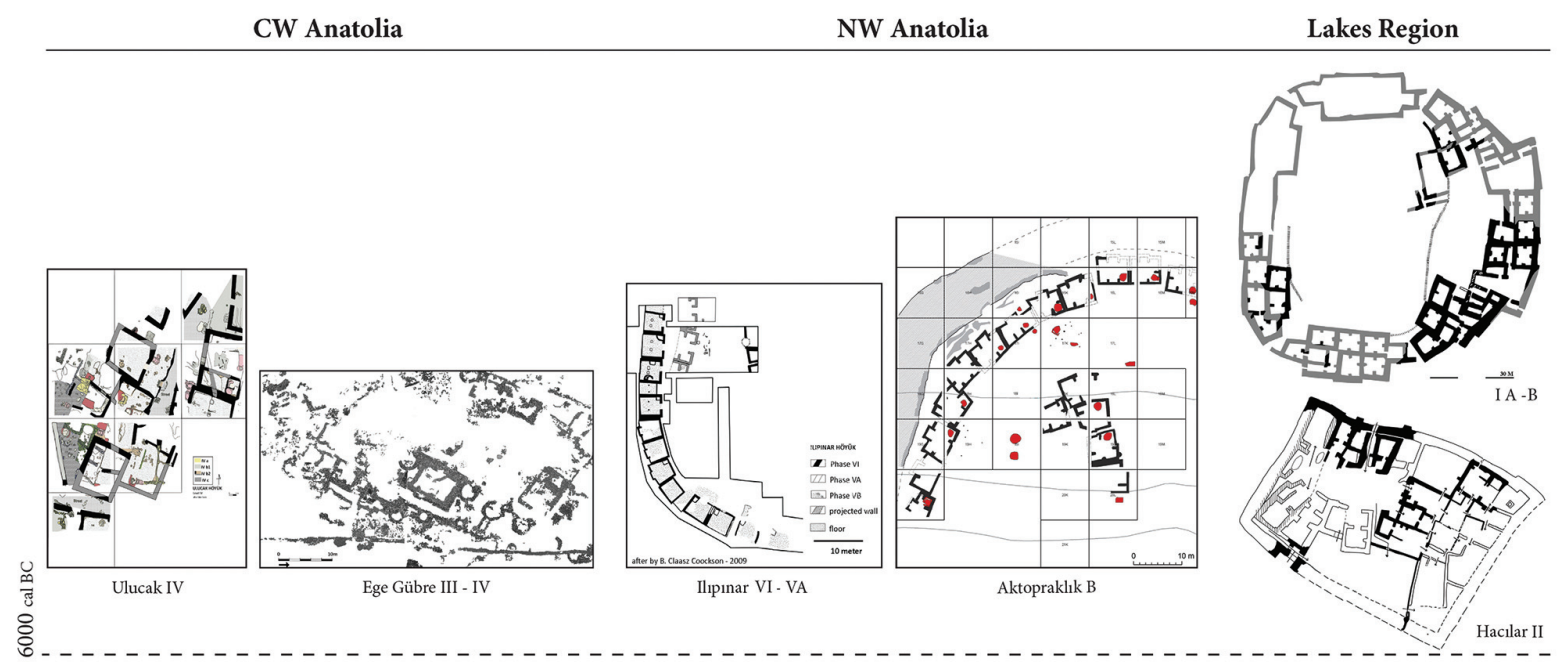

Fig. 6. Ulucak IV (after Çilingiroğlu et al. 2012.Fig. 4); Ege Gübre IV-III (after Sağlamtimur 2012.Fig. 3); Aktopraklhk B (after Karul, Avci 2013.Fig. 14); Ihpınar VI-VA (after Roodenberg, Alpaslan-Roodenberg 2013.Fig. 2); Hacilar II and I (after Mellaart 1970.71, 89). 
ges that took place with the onset of the Pottery Neolithic, still within the Formative Zone, was the custom of extramural burials. Although known extramural cemeteries are extremely rare, it is possible to surmise their presence from the almost total absence of burials within the settlement areas (Campbell 1995). On the other hand, Central Anatolian, is one of the few places where intramural burial customs continue up until the end of the 7 th millennium BC, as extensively documented at sites such as Çatalhöyük, Tepecik-Çiftlik and Köşk Höyük (Boz, Hager 2014; Bıçakçı et al. 2012; Öztan 2012). Additionally, at Kössk Höyük, skull practices continue into the $6^{\text {th }}$ millennium BC (Özbek 2009).

In Northwest Anatolia, burial customs show parallels with Central Anatolia. Intramural burials or burials under house floors are common at sites during the 7th millennium BC (Özdoğan 2013; Lillie et al. 2012; Alpaslan et al. 2013; Roodenberg, Alpaslan-Roodenberg 2013). Most burials are in the hocker position and buried with grave goods such as bone spoons, whole pots, or polypod vessels. However, by the $6^{\text {th }}$ millennium $\mathrm{BC}$, burials had moved out of the settle-

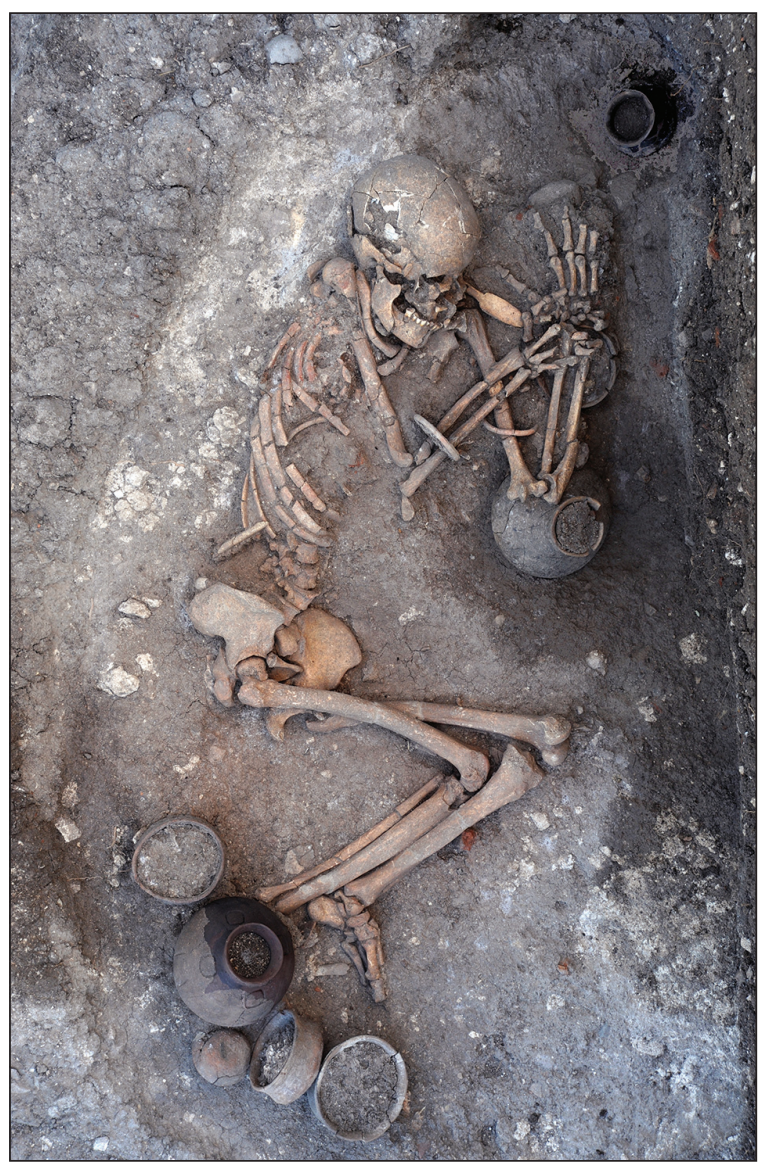

Fig. 7. Early Chalcolithic burial with grave goods from Aktopraklhk graveyard in Area C (after Karul, Avc1 2013.Fig. 6). ment to graveyards (Fig. 7), as seen at Aktopraklık (Karul, Avcr 2013).

The cemetery of the Early Chalcolithic settlement (Area B) is about $200 \mathrm{~m}$ north of the site in Area A which contains the remains of a Late Neolithic settlement. However, in spite of the development of special cemeteries by the first half of the $6^{\text {th }}$ millennium $\mathrm{BC}$, the practice of intramural burial continued, as evidenced at Aktopraklık and Ilıpınar. Examples from Aktopraklık include single or double burials in extraordinary positions excavated beneath the central courtyard of the settlement (Karul, Avcr 2013. 50). Some human bones have also been found mixed with stones. At Ilıpınar, burials are also found in various positions, sometimes found lying on a wooden plate; however, most of the intramural burials at this site are small children and newborn babies (Roodenberg, Alpaslan-Roodenberg 2013).

Intramural burials and their associated customs are phenomena also found in the Lakes District, although not as frequently as in Northwest Anatolia. A number of human skulls were discovered in structures at Aceramic Hacilar, which is considered to be the earliest settlement in the region (Mellaart 1970.6). Remains in a hocker position were found in pits at Bademağacı EN I and II, Hacılar IV, III, and Kuruçay 11, although there are few in number (Duru 2008. 51; Mellaart 1970.Fig. 43; Duru 1994.18). At Höyücek, a single child's grave was found in an area dating to the ShP or SP phase (Duru, Umurtak 2005. 26). Unlike in the other two regions, there are no burials at sites in Central-west Anatolia or the northern Aegean, with the exception of Ege Gübre, where one individual was found buried in a hocker position (Sağlamtimur 2012.32).

\section{Material culture and symbolism}

The early stages of the Neolithic, particularly in the northern parts of the formative zone, are exemplified by the extensive presence of symbolic elements, monumental communal buildings, and the use of special crafts that require sophisticated technologies and elaborate workmanship; however, with the transitional stage to the Pottery Neolithic, there is a clear decline in almost all of these (Rollefson, Köhler-Rollefson 1989; Özdoğan 2014b). The Aceramic Neolithic in Central Anatolia shows parallels with the Pre-Pottery Period in the east in terms of features like public buildings, painted floors, and intramural burial customs, etc. (Özbaşaran 2011). However, contrary to the decline in east, symbolic ele- 
ments in Central Anatolia increase during the Pottery Neolithic, as best known at Çatalhöyük, Tepecik-Çiftlik and Kösk Höyük (Hodder 2012; Biçakçı et al. 2012; Öztan 2012). Although symbolic expressions are far more limited in Western Anatolia, some need to be described nevertheless.

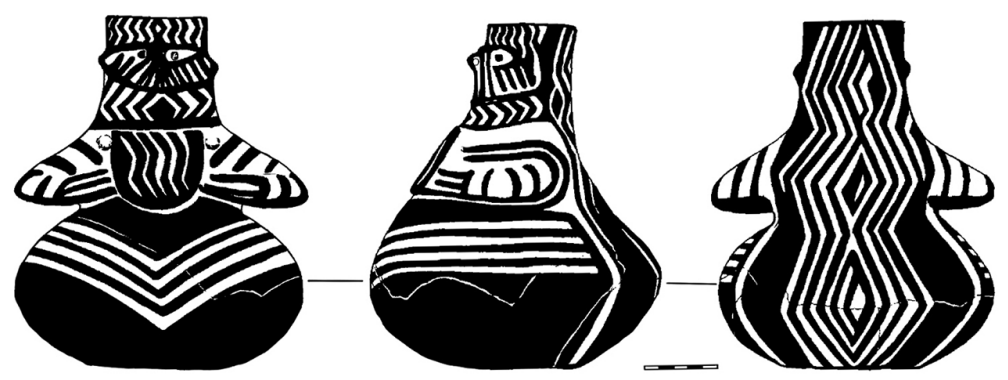

The distribution of symbolic elements

Fig. 8. Anthropomorphic vessel from Hacılar I (after Mellaart 1970. Fig. 525).

in Western Anatolia is not uniform; some elements are found in some districts, while other elements exist in other regions. For example, in Central-west Anatolia and the Lakes District, anthropomorphic (Fig. 8) or zoomorphic vessels occur, while in Northwest Anatolia they are absent. Bull symbolism is notably present in Central Anatolia, and is found on vessels in the form of relief decoration, mainly in the Lakes District and Central-west Anatolia (and sometimes in the form of painted decoration, see Kuruçay (Duru 1994.Fig. 56)), but in Northwest Anatolia, it seems to appear only as a variation of horizontal lugs, and very rarely (Karul, Avcr 2011). Additionally, polypod vessels known from Central Anatolia exist both in the Lakes District and Northwest Anatolia, but these are not present in Central-west Anatolia (Schwarzberg 2005). Polypod vessels are far more common in Northwest Anatolia (Fig. 9) and are considered a characteristic feature of the 'Fikirtepe Culture'.

Human figures, mostly depicting females, are quite common both in the Lakes District and in Central Anatolia (Duru 2008.Fig. 152, 157-162, 164-168). On the other hand, in Central-west and Northwest Anatolia these are less common than in the Lakes District (Gerritsen et al. 2013b.Fig. 17). Some anthropomorphic figures in Central-west Anatolia can be found on vessels in the form of appliqués, which strongly resemble the three-dimensional examples found in the same region (Cilingiroğlu et al. 2012. Fig. 8; Sağlamtimur 2012.Fig. 17).

Northwest Anatolia is particularly different from the other two regions with regard to the distribution of symbolic elements. In addition to the scarcity of figurines, objects such as pintaderas, stone vessels, and high-quality stone finds such as amulets or pendants etc., did not exist - especially not in the 7 th millennium $\mathrm{BC}$ - in this region, as they did in the Lakes District and Central-west Anatolia. Although sling missiles are common throughout Western Anatolia, arrowheads are non-existent in Northwest Anatolia in contrast to other regions (Özdoğan 2002). On the other hand, finds such as bone spoons (Fig. 10), hooks or fine bone tools are present in all three regions, but bone tool technology; bone spoons and spatulas are notably more common at Northwest Anatolian sites (Özdoğan 2013; Gerritsen et al. 2013a; Karul, Avcr 2013).

\section{Conclusion}

One of the most typical features of the Western Anatolian Neolithic is the continuity of settlements. After the establishment of settlements in the region, most survived until the Early Chalcolithic period, but only a few until the end of the Neolithic (Fig. 2). However, in Northwest Anatolia, some coastal settlements lasted for a relatively shorter period, such as Fikirtepe and Pendik. It might also be appropriate to add Höyücek, Kuruçay and Ege Gübre to the list of settlements that lasted for a more limited time. The continuity of the settlements is a reflection of overall regional continuity, and thus it is seen not only in the stratigraphy but also in the material culture. The features that characterise each region seem to have emerged immediately after this initial phase, shaped by local dynamics.

Intensive interactions can be traced between different areas of the formative zones and other sub-re-

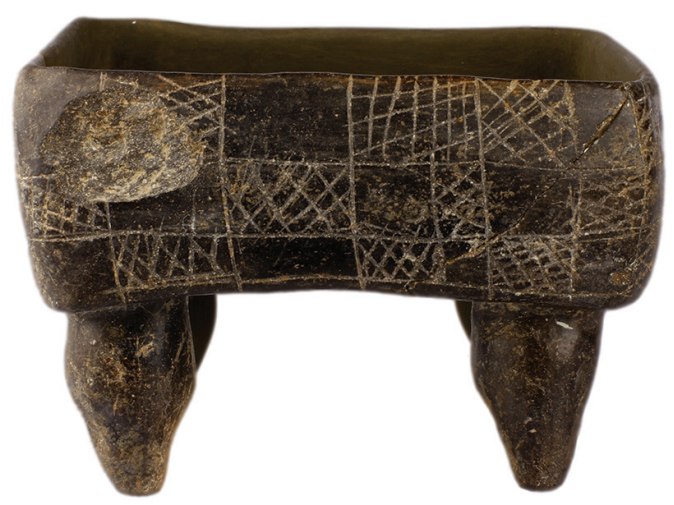

Fig. 9. Polypod vessel from Fikirtepe (after Özdoğan 2013.Fig. 9). 


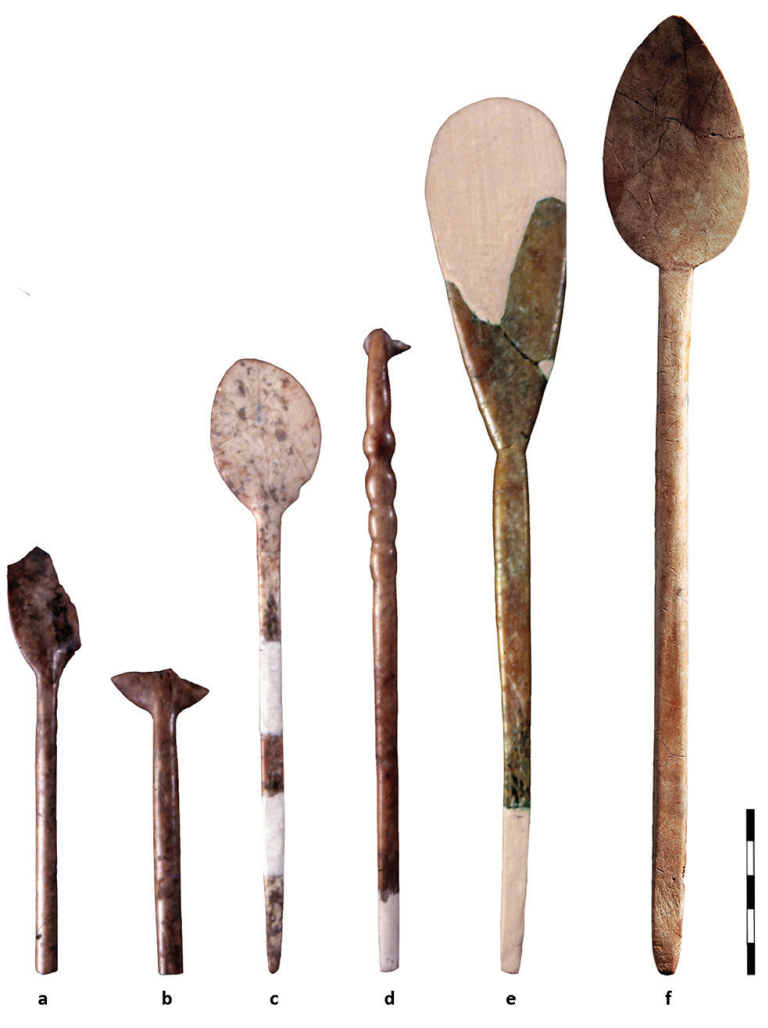

Fig. 10. Bone spoons from Northwest Anatolia, a-e from Fikirtepe and Pendik (after Özdoğan 2013. Fig. 14); f from Aktopraklk B (after Karul, Avc1 2013.Fig. 22).

gions in Western Anatolia. Painted pottery being common in the Lakes District, in the southern parts of Central Anatolia and as well along the Mediterranean coastline and in northern Mesopotamia it is extremely rare in the western and northern parts of the Anatolian Plateau. Instead, there seems to be a tradition of red-slipped pottery in the Central-west, while, in northwestern parts it is supplanted by dark monochrome ware. Impresso decoration appears in the last quarter of the $7^{\text {th }}$ millennium BC in Centralwest Anatolia, and at the beginning of the next millennium in Northwest Anatolia, probably the result of interaction with Mediterranean and Aegean sites. Western Anatolia has some connections with the formative zones, as well as with networks emerging in the Aegean and Mediterranean; in addition to pottery traditions, the presence of Aegean and Central Anatolian obsidian is among the main evidence for these connections (Milić 2016). Likewise, female figurines, red-slipped ware, bull representations, mud brick architecture, intramural burial customs etc., are all indicators of strong parallels with Central Anatolia.

The continuity of cultural elements in Western Anatolia, the Aegean, and Greece suggest that the expansion of the Neolithic did not extend along a de- fined frontier line, but must have been a massive phenomenon. Nevertheless, it is more evident that the expansion of the Neolithic way of life was a multifarious event that cannot be explained by a single model. Accordingly, it has to be taken case by case, each having its own particular modalities defined by local conditions and relationships with different parts of the formative zone. Furthermore, all three sub-regions in Western Anatolia sustained interactions with Central Anatolia. They had their own distinct interrelations; thus, the features that the Lakes District had in common with Central-west Anatolia and Northwest Anatolia are greater than the similarities between the latter regions.

It is possible to categorise the cultural changes that took place in Western Anatolia in distinct time frames (Özdoğan 2008; 2011). The earliest Neolithic settlements outside of the formative zone had begun to appear by the second quarter of the $7^{\text {th }}$ millennium BC, and their number seems to have increased in the middle of the same millennium. Following the formation of the first few early settlements, there must have been a massive movement, subsequently leading to the establishment of new settlement sites. In the next stage, approximately at 6200-6000 BC, with the spread of painted pottery and impressed decoration, significant changes take place in the cultural setting. During this stage, newly Neolithised areas beyond the formative zone began taking on a role as new or secondary cores. Thus, by this stage, the Mediterranean, the Aegean, and/or Western Anatolia can be regarded as new cores.

In this respect, the expansion of the Neolithic way of life into the Balkans must have been through different routes and networks of interaction, as elements were carried on from different regions through Anatolia, the Aegean and Greece. A substantial increase in the number of settlements in the Balkans took place between 6000 and $5900 \mathrm{BC}$. This expansion, as the settlements appeared over a wide area, must have been associated with some global fluctuations rather than the internal dynamics of sub-regions. On the other hand, these dates fit the climatic events suggested recently by Bernhard Weninger and his colleagues (Weninger et al. 2015).

The beginning of the $6^{\text {th }}$ millennium $\mathrm{BC}$ is conventionally considered as marking the chronological division between the Late Neolithic and Early Chalcolithic periods; however, no significant changes can be observed in the cultural assemblages of the sites in the western and southern coasts of the pen- 
insula. On the other hand, in Central and Northwest Anatolia, marked changes took place during that time. In addition to the change observed in material culture, the location of the Neolithic settlement at Aktopraklık moved $200 \mathrm{~m}$ south, the settlements at Menteşe and Barcin ended, and new settlements like Ilıpınar emerged. New settlements such as Kanlıtaş and Orman Fidanlığ located along the valley of the Sakarya River connecting the Marmara region with inner Anatolia, and Gelveri in Central Anatolia (Türkcan 2015; Efe 2001; Özbudak 2012) define the formation of the Chalcolithic as far back as the early $6^{\text {th }}$ millennium BC. The changes taking place in this period can especially be seen at Çatalhöyük West and Canhasan in the southern part of Central Anatolia (Biehl, Rogasch 2013; French 2005). During this period, interaction between Central and Northwest Anatolia seems to have accelerated. Appearing first at Aktopraklık and then at Ilıpınar, the tradition of building structures with buttresses and mud brick walls reflects the same traditions as at Canhasan or at Çatalhöyük. However, over time the mud brick structures in Northwest Anatolia came to be built with circular plans, continuing the layout of the previous period. These structures are arranged in adjacent lines at Barcin VId, an entirely different design from the agglomerate settlement pattern of Central Anatolia. The same phenomenon has also been evidenced in the Lakes District at Hacilar I and Kuruçay 7 , where the structures have mud brick walls with buttresses. Although construction techniques and the other features show many similarities between the areas and prove the existence of interaction between the regions, it is difficult to say that the features in each region were transferred wholesale from one to another. Local adaptation processes seem to have played a major role in each sub-region in Western Anatolia, while incorporating new elements.

\section{References}

Alpaslan-Roodenberg M. S., Gerritsen F. A. and Özbal R. 2013. Neolithic Burials from Barcin Höyük: The 20072012 Excavation Seasons. Anatolica 39: 93-111.

Arbuckle B. S. 2013. The Late Adoption of Cattle and Pig Husbandry in Neolithic Central Turkey. Journal of Archaeological Science 40: 1805-1815.

Arbuckle B. S. and 23 co-authors 2014. Data Sharing Reveals Complexity in the Westward Spread of Domestic Animals across Neolithic Turkey. PLoS ONE 9(6): 1-11.

Asouti E. 2006. Beyond the Pre-Pottery Neolithic B Interaction Sphere. Journal of World Prehistory 20: 1-40.

Bailey D., Whittle A. 2005. Unsettling the Neolithic: breaking down concepts, boundaries and origins. In D. Bailey, A. Whittle and V. Cummings (eds.), (un)settling the Neolithic. Oxbow Books. Oxford: 1-10.

Biehl P., Rogasch J. 2013. Excavations in Trench 5, West Mound. Catalhöyük Archive Report 2013: 94-110.

Bittel K. 1969. Bemerkungen über die prähistorische Ansiedlung auf dem Fikirtepe bei Kadıöy (Istanbul). Istanbuler Mitteilungen 19/20:1-19.

Bıçakçı E., Godon M. and Çakan Y. G. 2012. Tepecik Çiftlik. In M. Özdoğan, N. Başgelen and P. Kuniholm (eds.), Neolithic in Turkey: New Excavations and New Research. Central Turkey. Arkeoloji ve Sanat Yayınları. Istanbul: $89-134$.
Boessneck J., von den Driesch A. 1979. Die Tierknochenfunde aus der Neolithischen Siedlung auf dem Fikirtepe bei Kadıköy am Marmarameer, Aus dem für Paleoanatomie. Domestikationsforschung und Geschichte der Tiermedizin der Universität München. München.

Bordaz J. 1973. Current Reseach in the Neolithic of South Central Anatolia: Suberde, Erbaba and Their Chronological Implications. American Journal of Archaeology 77(3): 282-288.

Boz B., Hager L. D. 2014. Making Sense of Social Behaviour from Disturbed and Commingled Skeletons: A Case Study from Çatalhöyük Turkey. In A. Osterholtz, K. M. Baustian and D. Martin (eds.), Commingled and Disarticulated Human Remains. Working Toward Improved Theory, Method, and Data. Springer. New York, Heidelberg, Dordrecht, London: 17-33.

Bogucki P. 2003. Neolithic dispersals in riverine interior central Europe. In A. J. Ammerman, P. Biagi (eds.), The widening harvest. The Neolithic Transition in Europe: looking back, looking forward. Archaeological Institute of America. Boston: 249-272.

Brami M. N. 2014. A Graphical Simulation of the 2,000year Lag in Neolithic Occupation between Central Anatolia and the Aegean Basin. Archaeological and Anthropological Sciences 7(3): 319-327.

Brami M., Heyd V. 2011. The origins of Europe's first farmers: The role of Hacilar and Western Anatolia, fifty years on. Prähistorische Zeitschrift 86(2): 165-206. 
Budja M. 2009. Early Neolithic pottery dispersals and demic diffusion in Southeastern Europe. Documenta Praehistorica 36: 117-137.

2013. Neolithic Pots and Potters in Europe: the end of 'demic diffusion' migratory Model. Documenta Praehistorica 40: 39-55.

Campbell S. 1995. Death for the Living in the Late Neolithic in North Mesopotamia. In S. Campbell, A. Green (eds.), Archaeology of Death in the Ancient Near East. Oxbow. Oxford: 29-34.

Childe V. G. 1929. The Danube in Prehistory. Clarendon Press. Oxford.

1939. The Orient and Europe. American Journal of Archaeology 43(1): 10-26.

Çilingiroğlu A., Derin Z., Ebay E., Sağlamtimur H. and Kayan I. 2004. Ulucak Höyük: Excavations Conducted between 1995-2002. Ancient Near Eastern Supplement 15. Peeters. Louvain.

Çilingiroğlu A., Çevik Ö. and Çilingiroğlu Ç. 2012. Towards Understanding the Early Farming Communities of CentralWestern Anatolia: Contribution of Ulucak. In M. Özdoğan, N. Başgelen and P. Kuniholm (eds.), Neolithic in Turkey: New Excavations and New Research. Western Turkey. Arkeoloji ve Sanat Yayınları. Istanbul: 139- 175.

Çilingiroğlu Ç. 2016. Impressed Pottery as a Proxy for Connectivity in the Neolithic Aegean and Eastern Mediterranean. In B. P. C. Molloy (ed.), Of Odysseys and Oddities, Scales and modes of interaction between prehistoric Aegean societies and their neighbours. 0xbow. 0xford, Philadelphia: 75-96.

Çilingiroğlu Ç., Çakırlar C. 2013. Towards Configuring the Neolithization of Aegean Turkey. Documenta Praehistorica 40: 21-29.

Derin Z. 2012. Yeşilova Höyük. In M. Özdoğan, N. Başgelen and P. Kuniholm (eds.), Neolithic in Turkey: New Excavations and New Research. Western Turkey. Arkeoloji ve Sanat Yayınlar1. Istanbul: 177-195.

Duru R. 1989. Were the earliest cultures at Hacilar really aceramic? In K. Emre, M. Mellink, B. Hronda and N. ÖZgüç (eds.), Anatolia and the Ancient Near East. Studies in Honor of Tahsin Özgüc. Türk Tarih Kurumu Basımevi. Ankara: 99-105.

1994. Kuruçay Höyük I. 1978-1988 Kazlarının Sonucları, Neolitik ve Kalkolitik Çă Yerleşmeleri. Türk Tarih Kurumu. Ankara.

2008. MÖ 8000'den MÖ 2000'e BurdurAntalya Bölgesi'nin Altıbin Yılı. Suna-Inan Kıraç Akdeni Medeniyetleri Araştırma Enstitüsü. Antalya.
Duru R., Umurtak G. 2005. Höyücek, 1989-1992 Yillar Arasında Yapılan Kazıların Sonucları. Türk Tarih Kurumu. Ankara.

Efe T. 2001. The Salvage Excavations at Orman Fidanliğı. A Chalcolithic Site in Inland Northwestern Anatolia. TASK Yayınları. Istanbul.

Efstratiou N. 2013 Knossos and the Beginning of the Neolithic in Greece and the Aegean Islands. In N. Efstratiou, A. Karetsou and M. Ntinou (eds.), The Neolithic Settlement of Knossos in Crete New Evidence for the Early Occupation of Crete and the Aegean Islands. INSTAP Academic Press. Philadelphia, Pennsylvania: 201-214.

Erdal Y. S. 2015. Bone or Flesh: Defleshing and Post-Depositional Treatments at Körtik Tepe (Southeastern Anatolia, PPNA Period). European Journal of Archaeology 18(1): 4-32.

Erdoğu B. 2013. Uğurlu: A Neolithic Settlement on the Aegean Island of Gökçeada. In M. Özdoğan, N. Başgelen and P. Kuniholm (eds.), Neolithic in Turkey: New Excavations and New Research. Northwestern Turkey and Istanbul. Arkeoloji ve Sanat Yayınları. Istanbul: 1-33.

Evershed R. P. and 21 co-authors. 2008. Earliest Date for Milk Use in the Near East and Southeastern Europe Linked to Cattle Herding. Nature 455: 528-531.

French D. 1965. Early Pottery Sites from Western Anatolia. Bulletin of the Institute of Archaeology V: 15-24.

2005. Canhasan I: The Pottery. British Institute of Archaeology at Ankara No. 32. Ankara.

Fort J. 2015. Demic and cultural diffusion propagated the Neolithic transition across different regions of Europe. Journal of The Royal Society Interface 12: 1-8.

Garašanin M. 1954. Iz istorije mlageg neolita u Srbiji i Bosni. Glasnik Zemaljskog muzeja u Sarajevu IX: 5-39.

Gatsov I., Schwarzberg H. (eds.) 2006. Aegean-Marmara-Black Sea Present state of the resarch of the Early Neolithic. Proceedings of the Session held at the EAA $8^{\text {th }}$ Annual Meeting at Thessaloniki, 28th September 2002. Beier and Beran. Langenweissbach.

Gerritsen F., Özbal R. and Thissen L. 2013a. Barcin Höyük: The Beginnings of Farming in the Marmara Region. In M. Özdoğan, N. Başgelen and P. Kuniholm (eds.), Neolithic in Turkey: New Excavations and New Research. Northwestern Turkey and Istanbul. Arkeoloji ve Sanat Yayınları. Istanbul: 93-112.

Gerritsen F., Özbal R. and Thissen L. 2013b The Earliest Neolithic Levels at Barcın Höyük, Northwestern Turkey. Anatolica 39: 53-92. 
Harmankaya S. 1983. Pendik Kazısı 1981. IV. Kazı Sonucları Toplantısı I: 25-30.

Harris D. R. 2003. Paradigms and Transitions: Reflections on the Study of the Origins and Spread of Agriculture. In A. J. Ammerman, P. Biagi (eds.), The Widening Harvest The Neolithic Transition in Europe: Looking Back, Looking Forward. Archaeological Institute of America. BostonMA: 43-58.

Hodder I. 2012. Renewed Work at Çatalhöyük. In M. Özdoğan, N. Başgelen and P. Kuniholm (eds.), Neolithic in Turkey: New Excavations and New Research. Northwestern Turkey and Istanbul. Arkeoloji ve Sanat Yayınları. Istanbul: 245-277.

Hofmanová and 38 co-authors. 2016. Early farmers from across Europe directly descended from Neolithic Aegeans. Proceedings of the National Academy of Sciences of USA 113: 6886-6891.

Horejs B. 2012. Çukuriçi Höyük: A Neolithic and Bronze Age Settlement in the Region of Ephesos. In M. Özdoğan, N. Başgelen and P. Kuniholm (eds.), Neolithic in Turkey: New Excavations and New Research. Western Turkey. Arkeoloji ve Sanat Yayınları. Istanbul: 117-131.

Horejs B., Milić B., Ostmann F., Thanheiser U., Weninger B. and Galik A. 2015. The Aegean in the Early 7th Millennium BC: Maritime Networks and Colonization. Journal of World Prehistory 28: 289-330.

Kansu S. A. 1963. Marmara Bölgesi ve Trakya'da Prehistorik Iskan Tarihi Bakımından Araştırmalar (1959-1962). Belleten 27: 657-705.

Karul N. 2011. The Emergence of Neolithic Life in South and East Marmara Region. In R. Krauß (ed.), Beginnings New research in the appearance of the Neolithic between Northwest Anatolia and the Carpathian Basin. Papers of the international workshop. $8^{\text {th }} 9^{\text {th }}$ April 2009 Istanbul. VML Verlag Marie Leidorf. Rahden: 57-65.

Karul N., Bertram J. 2005. From Anatolia to Europe: The Ceramic Sequence of Hoca Çeşme in Turkish Thrace. In C. Lichter (ed.), How Did Farming Reach Europe? Anatolian-European Relations from the Second Half of the 7 th Though the First Half of the $6^{\text {th }}$ Millennium Cal. BC. Proceedings of the International Workshop Istanbul, 20-22 May 2004. BYZAS 2. Veröffentlichungen des Deutschen Archaeologischen Instituts Istanbul. Ege Yayınları. Istanbul: $117-130$

Karul N., Avc1 M. B. 2011. Neolithic Communities in the Eastern Marmara Region: Aktopraklık C. Anatolica 37: $1-15$.

2013. Aktopraklık. In M. Özdoğan, N. Başgelen and P. Kuniholm (eds.), Neolithic in Turkey: New Excava- tions and New Research. Northwestern Turkey and Istanbul. Arkeoloji ve Sanat Yayınları. Istanbul: 45-68.

Krauß R. (ed.) 2011. Beginnings - New research in the appearance of the Neolithic between Northwest Anatolia and the Carpathian Basin. Papers of the international workshop. $8^{\text {th }}$-9th April 2009, Istanbul. VML Verlag Marie Leidorf. Rahden.

Kızıltan Z. 2013. Pendik Höyük Kazıları. Aktüel Arkeoloji 34: 32-36.

Kiziltan Z., Polat M. A. 2013. The Neolithic at Yenikap1 Marmaray: Metro Project Rescue Excavations. In M. Özdoğan, N. Başgelen and P. Kuniholm (eds.), Neolithic in Turkey: New Excavations and New Research. Northwestern Turkey and Istanbul. Arkeoloji ve Sanat Yayınları. Istanbul: 113-165.

Lazaridis I. and 52 co-authors. 2016. Genomic insights into the origin of farming in the ancient Near East. Nature 536: 419-426.

Lichter C., Meriç R. 2005. (eds.) How Did Farming Reach Europe? Anatolian-European relations from the Second half of the $7^{\text {th }}$ though the first half of the $\sigma^{\text {th }}$ millennium cal. $B C$. Proceedings of the International Workshop Istanbul, 20-22 May 2004. BYZAS 2. Veröffentlichungen des Deutschen Archaeologischen Instituts Istanbul. Ege Yayınları. Istanbul.

Lichter C., Meriç R. 2012. Dedecik-Heybetlitepe: Excavations at a Neolithic Settlement in the Torbalı Plain. In M. Özdoğan, N. Başgelen and P. Kuniholm (eds.), Neolithic in Turkey: New Excavations and New Research. Western Turkey. Arkeoloji ve Sanat Yayınları. Istanbul: 133-175.

Lillie M., Budd C., Alpaslan-Roodenberg S., Karul N. and Pinhasi R. 2012. Musings on Early Farming Communities in Northwest Anatolia; and other Flights of Fancy. IANSAInterdisciplinaria Archaeologica Natural Sciences in Archaeology III/II: 11-22.

Mathieson I. and 37 co-authors. 2015. Genome-wide patterns of selection in 230 ancient Eurasians. Nature 528: 499-503.

Mellaart J. 1967. Catalhöyük: A Neolithic town in Anatolia. Thames and Hudson. London.

1970. Excavations at Hacilar. Edinburgh University Press. Edinburgh.

Meriç R. 1993. Pre-Bronze Age Settlements of West-Central Anatolia. Anatolica XIX: 143-150.

Milić M. 2016. A Question of Scale? Connecting Communities through Obsidian Exchange in the Neolithic Aegean, Anatolia and Balkans. In B. P. C. Molloy (ed.), Of Odysseys 
and Oddities, Scales and modes of interaction between prehistoric Aegean societies and their neighbours. Oxbow. Oxford, Philadelphia: 97-121.

Milojčić V. 1949. Chronologie der jüngeren Steinzeit Mittel und Südosteuropas. Verlag Gebr. Mann. Berlin.

Ottoni C. and 36 co-authors. 2013. Pig domestication and human-mediated dispersal in western Eurasia revealed through ancient DNA and geometric morphometrics. $M o$ lecular Biology and Evolution 30: 824-832.

Özbaşaran M. 2011. The Neolithic on the Plateau. In S. R. Steadman, G. Mc Mahon (eds.), The Oxford Handbook of Ancient Anatolia 10,000-323 B.C.E. Oxford: 99-124.

Özbek M. 2009. Remodeled human skulls in Köşk Höyük (Neolithic Age, Anatolia): A new appraisal in view of recent discoveries. Journal of Archaeological Science 36: 379-386.

Özbudak M. 0. 2012. Kapadokya MÖ 6. Binyıl Kronolojisinin Kayıp Halkasi: Gelveri Çanak Çömleği Üzerine En Son Çalışmalar. Colloqium Anatolicum XI: 267-298.

Özdöl S. 2012. The Development and Traditions of Pottery in the Neolithic of the Anatolian Plateau. British Archaeological Reports IS 2439. Archaeopress. Oxford.

Özdoğan E. 2015. Current Research and New Evidence for the Neolithization Process in Western Turkey. European Journal of Archaeology 18(1): 33-59.

Özdoğan M. 1979. Fikirtepe. Unpublished PhD Thesis. Prehistory Department. Istanbul University. Istanbul.

1983. Pendik: A Neolithic Site of Fikirtepe Culture in the Marmara Region. In R. M. Boehmer, H. Hauptmann (eds.), Beiträge zur Altertumskunde Kleisasien, Festschrift für Kurt Bittel. Verlag Phillip von Zabern in Wissenschaftliche Buchgesellschaft. Mainz: 401-411.

1999. Northwestern Turkey: Neolithic Cultures in Between the Balkans and Anatolia. In N. Başgelen, M. ÖZdoğan (eds.), Neolithic in Turkey. Arkeoloji ve Sanat Yayinlari. Istanbul: 204-224.

2002. On Arrows and Sling Missiles: What Happened to the Arrows. In R. Aslan et al. (eds.), Mauerschau: Festschrift für Manfred Korfmann. Verlag Bernhard Albert Greiner. Remshalden- Grunbach: 437-444.

2008. An Alternative Approach in Tracing Changes in Demographic Composition: The Westward Expansion of the Neolithic Way of Life. In J. Bocquet-Appel, O. BarYosef (eds.), The Neolithic Demographic Transition and its Consequences. Springer. Heidelberg: 139-178.
2009. Earliest Use of Pottery in Anatolia. In D. Gheorghiu (ed.), Early Farmers, Late Foragers, and Ceramic Traditions: On the Beginning of Pottery in the Near East and Europe. Cambridge Scholars Publishing. Cambridge: $22-43$.

2011. Archaeological Evidence on the Westward Expansion of Farming Communities from Eastern Anatolia to the Aegean and the Balkans. Current Anthropology 52(4): 415-430.

2013. Neolithic Sites in the Marmara Region, Fikirtepe, Pendik, Yarımburgaz, Hoca Çeşme and Aşağı Pınar. In M. Özdoğan, N. Başgelen and P. Kuniholm (eds.), Neolithic in Turkey: New Excavations and New Research. Northwestern Turkey and Istanbul. Arkeoloji ve Sanat Yayınları. Istanbul: 167-269.

2014a. A new look at the introduction of the Neolithic way of life in Southeastern Europe. Changing paradigms of the expansion of the Neolithic way of life. Documenta Praehistorica 41: 33-49.

2014b. The Neolithic Collapse, or the Transition from the Pre-Pottery Neolithic to the Pottery Neolithic. In. B. Finlayson, C. Makarewicz (eds.), Settlement, Survey and Stone. Essays on Near Eastern Prehistory in Honour of Gary Rollefson. Ex oriente Berlin in collaboration with the CounBritish Research in the Levant. London: 169-175.

Öztan A. 2012. Köşk Höyük: A Neolithic Settlement in Niğde-Bor Plateau. In M. Özdoğan, N. Başgelen and P. Kuniholm (eds.), Neolithic in Turkey: New Excavations and New Research. Central Turkey. Arkeoloji ve Sanat Yayınlar1. Istanbul: 31-70.

Özsait M. 1993. Prospections archeologieques en Pisidie. Anatolica XIX: 195-210.

Pasinli A., Uzunoğlu E., Atakan N., Girgin Ç. and Soysal M. 1994. Pendik Kurtarma Kazısı IV. Müze Kurtarma Kazılart Semineri: 147-163.

Perlès C. 2001. Early Neolithic in Greece. Cambridge University Press. Cambridge.

2003. An Alternate and Old-Fashioned View of Neolithization of Greece. Documenta Praehistorica 30: 99-113.

Peschlow-Bindokat A., Gerber C. 2012. The Latmos-Beşparmak Mountains Sites With Early Rock Paintings in Western Anatolia. In M. Özdoğan, N. Başgelen and P. Kuniholm (eds.), Neolithic in Turkey: New Excavations and New Research. Western Turkey. Arkeoloji ve Sanat Yayınları. Istanbul: 67-115. 
Pinhasi R., Fort J. and Ammerman A. J. 2005. Tracing the Origin and Spread of Agriculture in Europe. PLOS Biology 3(12): 2220-2228.

Price T. D. (ed.) 2000. Europe's First Farmers. Cambridge University Press. Cambridge.

2015. Preceramic, Aceramic or Early Ceramic? The radiocarbon dated beginning of the Neolithic in the Aegean. Documenta Praehistorica 42: 147-158.

Renfrew C.1987. Archaeology and Language: The Puzzle of Indo-European Origins. Jonathan Cape. London.

Roodenberg J., van As A., Jacobs L. and Wijnen M. H. 2003. Early Settlement in the Plain of Yenişehir (NW Anatolia). The Basal Occupation Layers at Menteşe. Anatolica 29: 17-59.

Roodenberg J., Alpaslan-Roodenberg S. 2013. Ilipınar and Menteşe. Early Farming Communities in the Eastern Marmara, In M. Özdoğan, N. Başgelen and P. Kuniholm, (eds.), Neolithic in Turkey: New Excavations and New Research. Northwestern Turkey and Istanbul. Arkeoloji ve Sanat Yayınları. Istanbul: 69-91.

Schwarzberg H. 2005. Prismatic Polypod Vessels and Their Way to Europe. In C. Lichter (ed.), How Did Farming Reach Europe? Anatolian-European Relations from the Second Half of the $7^{\text {th }}$ Though the First Half of the $6^{\text {th }}$ Millennium Cal. BC. Proceedings of the International Workshop Istanbul, 20-22 May 2004. BYZAS 2. Veröffentlichungen des Deutschen Archaeologischen Instituts Istanbul. Ege Yayınları. Istanbul: 255-273.

Sağlamtimur H. 2012. The Neolithic Settlement of Ege Gübre. In M. Özdoğan, N. Başgelen and P. Kuniholm (eds.), Neolithic in Turkey: New Excavations and New Research. Western Turkey. Arkeoloji ve Sanat Yayınları. Istanbul: 197-225.

Rollefson G., Köhler-Rollefson I. 1989. The Collapse of Early Neolithic Settlements in the Southern Levant. In I. Hershkovitz (ed.), People and Culture Change. Proceedings of the Second Symposium on Upper Palaeolithic, Mesolithic and Neolithic Populations of Europe and the Mediterranean Basin. British Archaeological Reports IS 508. Archaeopress. Oxford: 59-72.

Schoop U. D. 2011. The Chalcolithic on the Plateau. In S. R. Steadman, G. McMahon (eds.), The Oxford Handbook of Ancient Anatolia (10,000-323 BCE). Oxford University Press. Oxford - New York: 150-173.

Seeher J. 1990. Coşkuntepe, Anatolisches Neolithikum am Nordostufer der Ägäis. Istanbuler Mitteilungen 40: 9-15.

Thissen L. 2001. The Pottery of Ilıpınar, Phase X to VA. In J. J. Roodenberg, L. C. Thissen (eds.), The Ilptnar Excavations II. Nederlands Institut Voor Het Nabije Oosten. Leiden: 3-154.

Thissen L., Özbal H., Türkekul-Bıyık A., Gerritsen F. and Özbal R. 2010. The Land of Milk? Approaching Dietary Preferences of Late Neolithic Communities in NW Anatolia. Leiden Journal of Pottery Studies 26: 157-172.

Thomas M. G., Kivisild T., Chikhi L. and Burger J. 2013. Europe and Western Asia: Genetics and Population History. In I. Ness, P. Bellwood (eds.), The Encyclopaedia of Global Human Migration. Wiley-Blackwell. Malden, Oxford: $146-156$.

Türkcan A. U. 2015. 2014 Eskişehir Kanlıtaş Höyük Çalışmaları. 36. Kazı Sonucları Toplantısı II: 685-697.

van Andel T. H., Runnels C. N. 1995. The earliest farmers in Europe. Antiquity 69: 481-500.

Weninger B., Clare L., Gerritsen F., Horejs B., Krauß R., Linstädter J., Özbal R. and Rohling E. J. 2014. Neolithisation of the Aegean and Southeast Europe during the 6600-6000 cal BC period of Rapid Climate Change. Documenta Praehistorica 41: 1-31.

Zeder M. A. 2011. The Origins of Agriculture in the Near East. Current Anthropology 52(4): 221-235.

Zilhão J. 1997. Maritime pioneer colonisation in the early Neolithic of the west Mediterranean. Testing the model against the evidence. Porocilo o raziskovanju paleolitika, neolitika in eneolitika $v$ Sloveniji 34: 19-42.

Zvelebil M. 2001. The Agricultural Transition and the Origins of Neolithic Society in Europe. Documenta Praehistorica 28: 1-26.

Zvelebil M., Lillie M. 2000. Transition to Agriculture in Eastern Europe. In T. D. Price (ed.), Europe's First Farmers. Cambridge University Press. Cambridge: 57-92. 